\title{
Logistics distribution network of tomato in Mexico
}

\section{Red de distribución logística de jitomate en México}

QUINTERO-RAMIREZ, Juan Manuel*i๋ ${ }^{1}$, OMAÑA-SILVESTRE, José Miguel ${ }^{2}$ and AYLLONBENITEZ, Julio Cesar ${ }^{3}$

${ }^{1}$ Cátedra CONACyT Ciudad de México, México.

${ }^{2}$ Colegio de Posgraduados, Campus Montecillo, Texcoco, Estado de México, México.

${ }^{3}$ Estudiante de Doctorado. Colegio de Posgraduados, Campus Montecillo, Texcoco, Estado de México, México.

ID $1^{\text {st }}$ Author: Juan Manuel, Quintero-Ramírez / ORC ID: 0000-0002-1040-2690, CVU CONACYT ID: 292056

ID $1^{\text {st }}$ Coauthor: José Miguel, Omaña-Silvestre / ORC ID: 0000-0002-5356-549X, CVU CONACYT ID: 59890

ID $2^{\text {nd }}$ Coauthor: Julio Cesar, Ayllon-Benítez / ORC ID: 0000-0002-5051-5411 CVU CONACYT ID: 506783

DOI: $10.35429 / J E S .2019 .5 .3 .25 .32$

Received July 06, 2019; Accepted November 13, 2019

\begin{abstract}
In this investigation, the shortage at national level of tomato is solved, where its logistics is scarce in its supply chain towards the demanding states that do not cultivate or harvest small quantities. The 32 states of the Mexican Republic are contemplated. The methodology is based on modelling on linear programming as an analysis tool, where tomato claiming states and supplying producer states are identified, to later identify the supply connections with the calculation including the logistics of transport costs between these states. By analysing and applying the method, results are obtained that demonstrate the optimization of the amounts to be distributed among the states (equilibrium between supply and demand), where one or more supplying states can supply the demanding state, minimizing transportation costs within its supply chain. The model determines the optimal connections between bidder-consumer, allowing the design of a Distribution Network in Mexico optimizing the supply of logistics in the supply chain.
\end{abstract}

Tomato, logistics, supply chain, linear programming

\begin{abstract}
Resumen
En esta investigación se resuelve el desabasto a nivel nacional de jitomate, donde su logística es escaza en su cadena de suministro hacia los estados demandantes que no cultivan o cosechan pocas cantidades. Se contemplan los 32 estados de la República Mexicana. La metodología se basa en la modelación sobre programación lineal como herramienta de análisis, donde se identifican los estados demandantes de jitomate y los estados productores oferentes, para posteriormente identificar las conexiones de suministro con el cálculo incluyendo la logística de costos de transporte entre estos estados. Al analizar y aplicar el método, se obtienen resultados que demuestran la optimización de las cantidades a distribuir entre los estados (equilibrio entre oferta y demanda), donde uno o más estados oferentes pueden abastecer al estado demandante, minimizando los costos de transporte dentro de su cadena de suministro. El modelo determina las conexiones optimas entre oferente-consumidor, permitiendo el diseño de una Red de Distribución en México optimizando el abasto en la logística en la cadena de suministro.
\end{abstract}

Jitomate, logística, cadena de suministro, programación lineal

Citation: QUINTERO-RAMIREZ, Juan Manuel, OMAÑA-SILVESTRE, José Miguel and AYLLON- BENITEZ, Julio Cesar. Logistics distribution network of tomato in Mexico. Journal-Economic Systems. 2019. 3-5: 25-32

\footnotetext{
* Correspondence to author ( Email: quintauro82@gmail.com)

$\dagger$ Researcher contributing as first author.
} 


\section{Introduction}

Red tomato or tomato is one of the vegetables that in Mexico is in great demand for the preparation of a great diversity of foods; either fresh or as a condiment preparation with other foods. The commercialization and diffusion achieved have made it become part of the diet of various cultures in the world over time, allowing us to occupy the second place in the world consumption of horticultural products (Olvera GJ et.al ., 2010).

According to the Tomato Product System (2015), red tomato or tomato is a very important economic activity in the north of the country, becoming one of the most promising items both for its demand and for its production; On the other hand, one of the limitations in the trade of this vegetable is the poor communication with the distributors due to the lack of coordination between the production points and the possible points of sale. This causes a high impact on the operating costs of the different distributors, as well as the performance of the supply chain directly affecting the storage costs, the increase in shrinkage, generating lag in delivery times, etc.

In Mexico, one of the problems with the tomato is a poor performance in its commercial distribution, which translates into a reduction of about $40 \%$ in the post-harvest period and that its consumption is not equitable at the national level; as well as the poor planning of a supply to the different states with high transport costs. The creation of a distribution network nationwide, allows to supply in a balanced way to all consumers, with the optimization of transportation costs. In order to carry out this research, information is identified to determine its modeling and programming, such as: consumer demand, the capacity of production units and the cost of transportation from each plant to consumers.

The methodology contains the decision variables such as the objective function and the supply and demand restrictions. Statistical data were obtained from official sources of information. In the closed market model, national production and consumption is considered. To define the objective function, all transport costs from each of the origins to each of the destinations must be known. In the supply restrictions, the origins and quantities available and, in the demands, the destinations and the quantities required.
Linear Programming (PL) is a technique that is used to obtain an optimal solution of a system of equations. When there are as many linear equations as unknowns it is possible to arrive at a unique solution of the system, or in those where there are more unknowns than equations there will be an infinite number of solutions (Ronald, 1972).

The results show which bidding states, according to the optimization of transport costs, can send to the demanding states of tomato, the necessary quantities, be it to one or several states which can supply according to the correct quantities demanded. To achieve a balance in the marketing of tomatoes in Mexico, distributors are required to compete in certainty, have the technical, financial and human resources to address the aspects of productivity, logistics, promotion and performance.

\section{Tomato consumption}

In Mexico, as in other parts of the world, the preference for fresh tomato consumption is predominant; It is also used as an industrialized product, for the preparation of pasta, sauces, purees, juices, etc .; derivatives that have gained importance in recent years, thanks to the technological advances achieved for their processing, as well as the tastes and customs of the new generations. This situation leads to greater demands on quality for distribution and sale in fresh, which in turn determines renewed niches and market conditions.

At present, transporting fresh products must maintain safety until consumer purchase to meet their nutritional needs.

According to the figures of the United States Department of Agriculture (USDA, 2012), Mexico exported in 2010 approximately 934,384 tons of red tomato to the United States of America (USA), becoming the main exporter of red tomato to the union American, thereby monopolizing $50 \%$ of the imports of red tomato in the US, already in 2012 it was reported that these exports increased with what Mexico exported about 1.1 million tons of red tomato to the US, representing $44 \%$ of the US market.

Likewise, the Institutional Trust in relation to Agriculture (FIRA, 2014), mentions that Mexico is the country that has the largest area and has had the greatest growth in recent years.

QUINTERO-RAMIREZ, Juan Manuel, OMAÑA-SILVESTRE, José Miguel and AYLLON- BENITEZ, Julio Cesar. Logistics distribution network of tomato in Mexico. Journal-Economic Systems. 2019 
The United States and Canada have slowed their growth due to the increase in labor and fuel costs. Canada is the country that produces the largest volume of greenhouse tomatoes; although Mexico is the one with the highest growth in recent years based on increasing the area. In Mexico, it is a crop with traditional roots whose consumption is daily in the Mexican diet. The harvested areas confirm the growth and consolidation that the vegetable has since the first decades of this century, which is why it was called the queen of vegetables. (Matus G., J. A., and Puente, G., A., 1993).

The global trade of fresh tomatoes is expanding, mainly, between neighboring countries, thanks to the reduction of tariffs (signing of trade agreements) and less transport costs derived from geographical proximity, as is the case of the United States of America, Canada and Mexico. Agrifood imports maintain a growing trend in the main centers of consumption in the world and represent a great opportunity for the continuity and growth of Mexican agri-food exports. It is required to have a logistic model that optimizes the operations of the tomato movement to the border and thus reduce costs, generating a proposal for the distribution of the production of the partners of the Tomato Product System based on the demand of its customers and the variables of decision involved. (SAGARPA, 2015).

For this research, fresh tomato production was estimated to be distributed by the consumer centers in the retail markets of the states of Mexico and the information was used for the year 2014, where a total sum of 2,875 thousand was reached. tons of this vegetable, according to the SIAP for that year. From this total amount, the exportable product, the quantity sent to industry and the waste (of approximately $40 \%$ in the post-harvest) was eliminated, and the scarce product that was imported from other countries was added. In that year, the average yield was 56.42 tons per hectare and had an average rural price of $\$$ $5,472.91$ per ton.

\section{Logistics and Supply Chain}

According to Ballou (2004), logistics is a set of functional activities that are repeated through the channel, in which the inputs are converted into finished products and subsequently sent to the consumer; and in each activity the product obtains an added value (cost).
In the same way, the interaction between the departments of a company must be connected under the system of working by processes, not by departments, with the perspective of internal client-supplier, improving the flow of the product or service for an effective administration of Supply Chain.

"The supply chain encompasses the business processes, people, organization, technology and physical infrastructure that allows the transformation of raw materials into intermediate and finished products and services that are offered and distributed to the consumer to meet their demand" (Pilot, 2015).

Chopra \& Meindl (2008), mention that supply chain management is important today, derived from the fact that organizations are achieving a significant competitive advantage because of the way they configure and manage supply chain operations.

Transportation is an important factor for the agribusiness sector, especially in the transfer of fresh produce. Considering that many of these are perishable, it is necessary that the means of transport provide adequate temperature and storage conditions so that the products arrive in good condition to the consumer and do not lose their quality ahead of time.

It is recommended that the organization controls the cleanliness of the units and maintains the safety of its products.

It is also essential to carry out a followup or traceability of all the processes through which the product passes, from its origin until it reaches the final consumer. The company must not only demonstrate that it can make the traceability of the products, but also can respond to any eventuality in the shortest possible time (Peña and Dávila, 2012).

\section{Linear Programming (LP)}

The need to work with given levels of fixed resources means that the typical PL solution is confined to short-term problems, which shows us a static nature of the model, since it is assumed that the facilities available for production are fixed and not they take into account the possibility of making changes (Ronald, 1972). 
Villalba Vilá (1990), proposes stages of the process of modeling PL problems that can be used in the case of other problems. The phases that stand out are, definition of variables, definition of restrictions, definition of the objective function, resolution and analysis of the solution.

The PL applied to the method of networks for the distribution of the tomato, allows to obtain competitive advantages in comparison with the optimization of material, financial and human resources; other secondary benefits such as lengthening production cycles, lower risk of loss of plant production with better organoleptic and plant characteristics free of toxic substances, which represent an opportunity and competitive advantage to participate in the market.

The transport problem is a special type of PL problem; It is known as transport because its applications determine the optimal way of transporting goods, although it has many other applications that have nothing to do with transport, as is the case with production scheduling. In its general form, the transport problem consists in determining the routes to be used and the quantities to be sent in a way that results in a minimum transport cost, having origin nodes with supplies and destination nodes with demands and knowing the transport costs between each of the points of origin and destination (Medina, 2007).

\section{Methodology}

In order to carry out the present investigation, the search for information was carried out in different sources, where statistics, official databases consulted and first-hand field information were obtained with transport agents in charge of distribution.

As there is only one merchandise, a destination can receive its demand from one or more sources. The basic assumption of the model is that the cost of transport on a route is directly proportional to the number of units transported (Taha, 1995).

In the execution of the model, the decision variables were integrated, such as the objective function and the supply and demand restrictions, as well as the transportation cost of the determined optimal routes.
In this closed market distribution model (national level), the following are considered variables: state production and consumption, among others. To define the objective function, all transport costs from each of the origins to each of the resulting destinations (optimal route) must be known. In the supply restrictions, the origins and quantities available and; in the demands, the destinations and the quantities required.

To carry out this analysis, information from the Agrifood and Fisheries Information Service (SAGARPA-SIAP), the National Population Council (CONAPO) and the 2010 Population and Housing Census of INEGI, Tariff Information System (SIAVI) of the Secretariat of Information Economy and the Ministry of Communications and Transportation (SCT), as well as direct information from land transport agents that integrated the transportation costs of the optimal routes that resulted. Once all the necessary information was collected and its processing was carried out, the nodes of the requesting and bidding states were obtained, which allowed obtaining and programming the transportation model and its distribution costs from the offering states to the complainants, calculating each of the routes to supply its distribution cost under the formula:

CTrans $=C F+C V(D)$

Where:

CTrans $=$ Transport cost

$\mathrm{CF}=$ Fixed Costs: Wages and salaries of management and management, insurance, taxes, rights, etc.

$\mathrm{CV}=$ Variable Costs: Fuel, maintenance, tires, truck expenses, operator, etc.

$\mathrm{D}=$ Distance between the offering node to the requesting node

An important factor for this model is the distance to travel; since for this modeling it was estimated on a 20 ton cargo truck, identifying the fixed and variable costs per ton. Also, the location of the nodes was located in the capital city, central supply or central city of each state. The cost of operation varies by the type and state of the roads; The higher the road roughness index, or what is the same, that shows greater deterioration, the cost of operation of the vehicle rises considerably, accentuating if the road has steep slopes and high levels of sinuousness. 
For the optimization of the fresh tomato distribution model, the objective function was elaborated considering the transport costs $\mathrm{C}_{\mathrm{ij}}$ of the origins $(m)$ to each of the destinations (n), multiplied by the quantity to be distributed (X) that should to be sent to each of them, representing as $\mathrm{X}_{\mathrm{nm}}$.

What the resulting objective function to execute in this model, is as follows:

$$
\operatorname{Min} Z_{0}=C_{11} X_{11}+C_{12} X_{12}+\ldots+C_{i j} X_{i j}
$$

Where:

$Z_{o}=$ Value of the objective function

$i=$ Index of the source state (bidder), where $i=1,2, \ldots, m$

$j=$ Destination State Index (complainant), where $j=1,2, \ldots, n$

$X_{i j}=$ is the amount of tomato assigned from origin $\mathrm{i}$ to destination $\mathrm{j}$.

$C_{i j}=$ represents the cost of transportation per ton of origin and destination $j$.

The model has as many supply restrictions as the number of origins i exist, and as many demand restrictions as the number of destinations $\mathrm{j}$ that exist.

In an abstract way, the closed market model seeks to optimize the distribution of tomatoes from producing entities with excess to states with low or no harvests, which, by structuring the objective function to minimize transportation costs in distribution, is formulated as follows:

\section{Objective Function:}

$\operatorname{Min} Z=\sum_{i=1}^{m} \sum_{j=1}^{n} C_{i j} X_{i j}$

\section{Subject to:}

$\sum_{i=1}^{m} X_{i j} \leq a_{i} \mathrm{i}=1, \ldots, \mathrm{m}$

$\sum_{j=1}^{n} X_{i j}=b_{j} \mathrm{j}=1, \ldots, \mathrm{n}$

$X_{i j} \geq 0 \quad \mathrm{i}=1, \ldots, \mathrm{m} \quad \mathrm{j}=1, \ldots, \mathrm{n}$

In formula 4 , it is indicated that all the flow of the product that is offered from the origin $i$ and that is sent to all possible $m$ destinations, cannot exceed the offer of the origin $i$ that is ai, where there is such a restriction by Each of the origins.
For formula 5, it indicates that all the flow of the product that is received at the consumption center $\mathrm{j}$ of all possible origins, must meet the demand of the consumption center $\mathrm{bj}$, where there is such a restriction for each demanding unit. In the case of formula 6 of NonNegativity, it indicates that the direction of product flow is from origins to destinations only (Quintero, 2014)

\section{Results}

With the information of all the required variables, the execution in PL projects the results with the optimization in the minimization of the transport costs of all the origins towards the centers of consumption to be able to supply all the states with this important vegetable.

When processing the information, the bidding states (origins or producing state) and demanding states (destinations or centers of consumption) are identified. Table 1 shows these statements with the supply amounts of the surplus states and demanding consumption centers (deficits). In this model, the balance between supply and demand is sought, everything that is produced, is all that is consumed.

Subsequently, a matrix of connection points of each surplus state was generated against the deficit states, calculating the minimum transport cost, having as standardized measure for the land transport of a 5-axis unit, with a $2.0 \mathrm{~km} / \mathrm{lt}$, fuel efficiency diesel; and, for the maritime, the quotation made on the ferry for transhipment from Baja California Sur to Sinaloa (to optimize the logistics route) was taken, according to the information in the MAPPIR application Trace your route from the Ministry of Communications and Transportation.

With this information an algorithm was generated with the PL method that identified the surplus states that distribute the lowest cost of transportation to the tomato to the deficit states with the quantities requested to supply the required demand, according to equation 3 . 


\begin{tabular}{|c|c|}
\hline \multicolumn{2}{|c|}{ Surplus Market } \\
\hline State & $\begin{array}{l}\text { Quantity } \\
\text { (Ton) }\end{array}$ \\
\hline $\mathrm{BCN}$ & $9,642.04$ \\
\hline BCS & $7,642.97$ \\
\hline Coah & $17,834.64$ \\
\hline Durg & $4,003.39$ \\
\hline Guaj & $16,040.38$ \\
\hline Jalc & $4,561.93$ \\
\hline Mich & $112,255.16$ \\
\hline Morl & $57,504.18$ \\
\hline Nayr & $22,020.02$ \\
\hline Oaxc & $42,099.20$ \\
\hline Qtro & $21,057.97$ \\
\hline SLP & $51,181.06$ \\
\hline Sinl & $30,065.35$ \\
\hline Sonr & $29,711.73$ \\
\hline Zacs & $76,766.32$ \\
\hline Total & $502,386.34$ \\
\hline
\end{tabular}

\begin{tabular}{|l|r|}
\hline \multicolumn{2}{|c|}{ Deficit Market } \\
State & $\begin{array}{c}\text { Quantity } \\
\text { (Ton) }\end{array}$ \\
\hline Agsc & 217.03 \\
\hline Camp & $8,032.76$ \\
\hline Colm & $1,886.44$ \\
\hline Chips & $29,725.01$ \\
\hline Chih & $32,252.59$ \\
\hline CDMX & $111,708.29$ \\
\hline Guer & $25,981.66$ \\
\hline Hidg & $6,525.89$ \\
\hline Méxc & $113,273.00$ \\
\hline NLeón & $25,272.66$ \\
\hline Pueb & $2,050.30$ \\
\hline Q Roo & $17,867.98$ \\
\hline Tabsc & $29,362.71$ \\
\hline Tamp & $6,024.53$ \\
\hline Tlax & $15,795.49$ \\
\hline Verz & $52,251.43$ \\
\hline Yuct & $24,158.56$ \\
\hline Total= & $\mathbf{5 0 2 , 3 8 6 . 3 4}$ \\
\hline
\end{tabular}

Table 1 Bidding and Claimant States of Tomato, in Mexico, 2016

Source: Own Elaboration with data from CONAPO and SAGARPA, 2014

With the programming tool to execute the PL of the mathematical model, the general objective function is integrated with the transportation costs of each route and the restrictions, both of supply and demand, which balance the quantities to be distributed according to the optimization of calculated transportation costs.

When developing the algorithm in PL focused on the objective function to minimize transportation costs, the interactions were executed to calculate each of the points of origin towards their different destinations, resulting in a matrix of 15 bidders for 17 plaintiffs, with a total amount of 255 possible combinations.

These combinations represent the optimal routes that the transport will use in the distribution of the vegetable.

From the results obtained with the PL, the states with surplus tomato production were identified, of which they have already supplied their own consumption of their population, being.
Baja California Norte and Sur with 2\% each; Durango and Jalisco with $1 \%$ each; Guanajuato 3\%; Michoacán with 22\%; Morelos with $11 \%$; with $4 \%$ each are Nayarit, Coahuila and Querétaro; Oaxaca 8\%; San Luis Potosí with $10 \%$; Sinaloa and Sonora with 6\% each; and Zacatecas $15 \%$; that well, they are called the offer and in the same way they identify the states with deficit consumption, which are: Aguascalientes with $0.04 \%$, Campeche with $1.6 \%$, Colima with $0.4 \%$, Chiapas with $5.9 \%$, Chihuahua with $6.4 \%$, Mexico City with $22.2 \%$, Guerrero with $5.2 \%$, Hidalgo with $1.3 \%$, Mexico with 22.6\%, Nuevo León 5\%, Puebla with $0.4 \%$, Quintana Roo $3.6 \%$, Tabasco with $5.8 \%$, Tamaulipas with $1.2 \%$, Tlaxcala with $3.1 \%$, Veracruz $10.4 \%$, and Yucatan with $4.8 \%$; which are called the demand; having a total net amount to distribute of: 502,386.34 tons (Table 1).

Table 2 shows the 15 surplus states where it is identified according to the optimization of the PL, where its totality or fraction is distributed, the surplus production they have to those deficit states; as well as, the result of optimizing the transport costs for distribution is minimized.

The road structure that exists in Mexico, plays a very important role in mapping the logistics routes, due to the types of roads existing for the determined means of transport, integrating all the expenses that may occur in the course of the trip and that were integrated in this investigation

\begin{tabular}{|c|c|}
\hline $\begin{array}{l}\text { Offering } \\
\text { State }\end{array}$ & $\begin{array}{l}\text { Amount of tomato sent to the requesting state (Cant- } \\
\text { edo / cant-edo /...) }\end{array}$ \\
\hline BCN & 9,642.04-Chih \\
\hline BCS & 1,886.44-Col / 2,050.30-Pue / 3,706.22-Tab \\
\hline Coah & $17,834.63-\mathrm{N} \mathrm{L}$ \\
\hline Dgo & 217.03-Ags / 3,786.36-CDMX \\
\hline Gto & 16,040.38-CDMX \\
\hline Jal & 4,561.93-Ver \\
\hline Mich & $\begin{array}{l}\text { 8,032.76-Camp / 15,493.93-EdoMex / 25,656.48-Tab / } \\
\text { 38,913.42-Ver / 24,158.56-Yuc }\end{array}$ \\
\hline Mor & 31,522.52-CDMX / 25,981.66-Gro \\
\hline Nay & 22,020.02-EdoMex \\
\hline Oax & 29,725.01-Chis / 12,374.19-Q.Roo \\
\hline Qro & 21,057.97-EdoMex \\
\hline S.L.P. & 51,181.07-CDMX \\
\hline Sin & 5,493.78-Q.Roo / 15,795.49-Tlax / 8,776.08-Ver \\
\hline Son & 22,610.55-Chih / 7,101.18-N L \\
\hline Zac & $\begin{array}{l}\text { 9,177.97-CDMX / 6,525.89-Hgo / 54,701.08-EdoMex / } \\
\text { 336.85-N L / 6,024.53-Tamps }\end{array}$ \\
\hline
\end{tabular}

Table 2 Matrix of Tomato Distribution Nodes in Mexico Source: Own Elaboration with summary of model results

QUINTERO-RAMIREZ, Juan Manuel, OMAÑA-SILVESTRE, José Miguel and AYLLON- BENITEZ, Julio Cesar. Logistics distribution network of tomato in Mexico. Journal-Economic Systems. 2019 
The results obtained in the model, it can be seen that the states of: Baja California distributes its $100 \%$ surplus to Chihuahua; Baja California Sur distributes its surplus $25 \%$ to Colima, $27 \%$ to Puebla and $48 \%$ to Tabasco; Coahuila distributes all its surplus to Nuevo León; Durango distributes its surplus 5\% to Aguascalientes and $95 \%$ to Mexico City; Guanajuato distributes its surplus to Mexico City; Jalisco to Veracruz $100 \%$ of its surplus; Michoacán distributes $7 \%$ to Campeche, $14 \%$ to the State of Mexico, 23\% to Tabasco, 35\% to Veracruz and $22 \%$ to Yucatán; Morelos distributes $55 \%$ of its surplus to Mexico City, $45 \%$ to Guerrero; Nayarit delivers its $100 \%$ surplus to the State of Mexico; Oaxaca distributes from its surplus $71 \%$ to Chiapas and $29 \%$ to Quintana Roo; Querétaro gives its $100 \%$ to the State of Mexico; San Luis Potosí distributes its $100 \%$ surplus to Mexico City; Sinaloa distributes from its surplus $18 \%$ to Quintana Roo, 53\% to Tlaxcala and 29\% to Veracruz; Sonora distributes its surplus $76 \%$ to Chihuahua and $24 \%$ to Nuevo León; Zacatecas distributes its surplus $12 \%$ to Mexico City, $9 \%$ to Hidalgo, $71 \%$ to the State of Mexico, $0.4 \%$ to Nuevo León and 8\% to Tamaulipas.

With this information of knowing the supplying and demanding states, it is possible to know graphically how the distribution network is generated at national level, as well as where the production to be consumed comes from; where one or several states can send part or all of their surplus production to the consumption center that requires fresh tomato.

In the Map of the Tomato Distribution Network in Mexico (figure 1), the interaction of surplus states together with deficit states to integrate the distribution network can be observed.

It can be seen that the states of the center and most of the southern states of the country have demand available; in the same way it is appreciated that to a large extent the northern states of the country have the availability to offer and that given the distance between them, the cost of transportation can be optimized to be able to supply the vegetable.

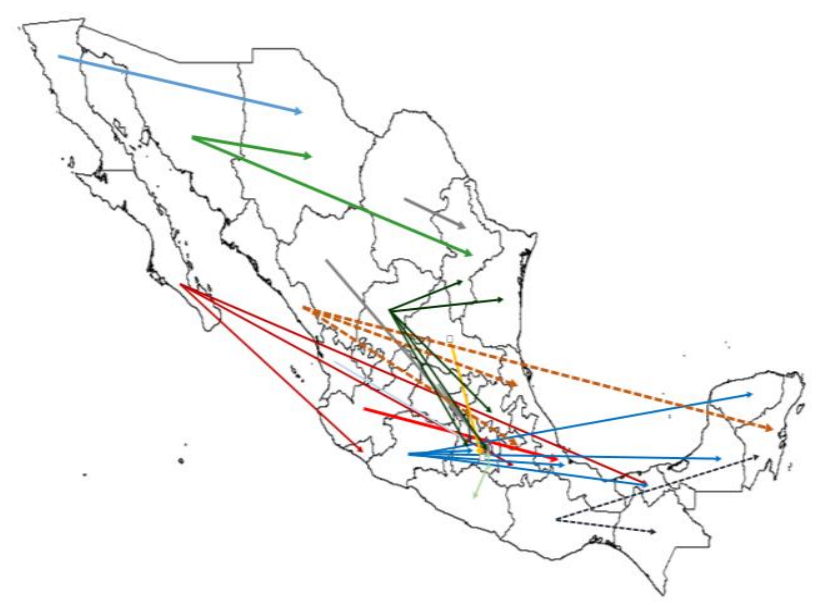

Figure 1 Map of the Tomato Distribution Network in Mexico

Source: Own Elaboration with data resulting from the model

Under the results obtained in the model, it can be seen that the supplying states selfsupply their consumption and distribute part of their surplus supply to be able to share it towards another deficit state; which demonstrates that the optimization of the model balances the quantity sent to be able to be efficient the cost of transporting said merchandise.

\section{Conclusions}

In the analysis of this research, transportation costs are optimized for fresh tomato distribution among surplus and deficit states in Mexico; since, when processing and optimizing the model, it results in the distribution of 502,386.34 tons, calculating its logistics with a minimum total transportation cost moving through the optimal federal highway routes equivalent to: \$ 2,956'440,000.00.

With the investigation carried out, the opportunity percentages of each deficit state are also identified in order to cover their local demand through the implementation of new production and distribution practices in their agrologistic sector.

The formulation and analysis of the PL for this type of modeling, provides relevant information to create optimal scenarios by simulating the data and also making the best decision among many alternatives; when those alternatives include satisfying several criteria at the same time and in the same way interacting with the restrictions of the process, thus allowing a good planning to be carried out before the correct consumption. 
This modeling allows to optimize the distribution of the national tomato production to those states lacking the product of those surplus states, making efficient the transport costs necessary for a good logistics in the distribution chain contemplating the distance between said points; thus allowing the creation of the national fresh tomato distribution network for Mexico.

The model developed in this research examines the optimization of transport costs due to the use of some practices that are not very suitable for quoting the transfer services; Some companies in this sector calculate their costs with a percentage below the competition with the objective of winning the transfer of the merchandise, but on the other hand they do not know the effect on the maintenance of the unit, the salaries of the operators, road accidents, fuel consumption, tire consumption, tolls, service quality, etc., so it is recommended to make this contribution to transport agents so that the different factors in the price of this service are taken into account.

The implementation of the Jitomate Distribution network connection in Mexico, implies developing a partnership for the national freight administration, with the premise of coordinating the operational rules of the logistics routes.

\section{References}

Ballou, R. H. (2004). Logística, Administración de la Cadena de Suministro. México: Pearson Educación.

Chopra, S., \& Meindl, P. (2008). Administración de la cadena de suministro. Estrategia, Planeación y Operación. México: Pearson Educación.

Coyle, Langley, Novack, Gibson (2013). Administración de la Cadena de Suministro. Una perspectiva Logística. Novena Edición. México: Editorial Cengage Learning.

Hernández, V. (2015). ¿Cómo diseñar una cadena de suministro dinámica? Logística Revistas Énfasis, 1-4.

J. Lieberman, F. S. (2015). Investigación de Operaciones. México: Mc Graw Hill.

Lee J. Krajewski, L. P. (2013). Administración de Operaciones. México: Pearson.

ISSN 2523-6350

RINOE® All rights reserved
Matus G., J. A., y Puente, G., A. (1993). Análisis estatal de los efectos de política económica y bases de la estrategia para la conversión de la agricultura. Sinaloa. Montecillo, Estado de México: Colegio de Postgraduados y Secretaría de Agricultura y Recursos Hidráulicos.

Olvera G. J, Sánchez R. J. R, Ochoa B. R, Rodríguez C. F, Roque Z. J, Ortega R. C, Palacios F. H. (2010). El jitomate. Revista Abriendo Surcos, 22-36.

Peña, T. y M. Dávila (2012) "Procesos logísticos en el sector agroindustrial" en Innova Supply Chain. Revisado en: http://innovasupplychain.pe/content/procesoslogisticos-en-el-sector-agroindustrial [Accesado el 23 de abril de 2015].

Quintero, JM. (2014). Análisis de la Logística para Exportación de Guayaba (Psidium guajava L.) en fresco a Estados Unidos de América. Colegio de Postgraduados Campus Montecillo, Texcoco Edo de México. Tesis Doctoral.

Quintero, JM. (2016). Modelo de Transporte para la Distribución de Guayaba (Psidium guajava L.) en México. Revista Mexicana de Ciencias Agrícolas Vol.7 núm.6 14 de agosto-27 de septiembre, 2016 p.1335-1346.

Ronald, F. J. (1972). Programación Lineal Aplicada. México: Editorial Técnica.

Repositorio de información de la Secretaría de Agricultura, Ganadería, Desarrollo Rural, Pesca y Alimentación. Revisado en http://www.gob.mx/sagarpa\#documentos [Accesado el 10 de noviembre de 2015].

Repositorio de USDA. México: Dairy and Products Annual. (01 de octubre de 2012). Revisado en http://www.fas.usda.gov [Accesado el 02 de Octubre de 2015].

Secretaria de Comunicaciones y Trasporte (2002). Marco conceptual de la cadena de suministro: Un nuevo enfoque logístico. Jiménez \& Hernández 